\title{
Italy recruits new faculty under old rules
}

Munich. Italy's minister of research and universities, apparently frustrated at parliamentary delays in approving new rules for the controversial concorsi - or national competitions - for university posts, last week announced a new round for 1,200 such positions under the existing rules.

Giorgio Salvini's move comes at a time of increasing public criticism of the concorsi system, widely believed to allow academic appointments to be based on personal connections rather than academic merit. The positions to be filled have remained empty for several years as argument has raged about whether appointments should be delayed until new laws aimed at reducing the opportunities for corruption have been passed by parliament.

The move also coincides with the discovery of 50 new cases of alleged corruption within concorsi selection committees, made up of professors from appropriate disciplines, which are being considered by the state prosecutor Adelchi D'Ippolito. Unlike the handful of previous challenges to

concorsi decisions, which were heard by administrative courts, the new charges reflecting the revolt against corruption that has swept Italy over the past three years are based on an alleged abuse of power, a criminal offence.

Indeed, the current level of public interest in the problems of academic appointments is reflected in the coining by the Italian press of a new term, cattedropoli (cattedra means chair), which, by analogy with the more familiar word tangentopoli used in recent investigations of political corruption, implies corrupt dealing.

Several cases are already coming to trial. Particular attention has been focused on the case of Corrado Manni, an anaesthesiologist at the Policlinico Gemelli in Rome, who treated the Pope when he was shot in St Peter's Square in 1981. Manni chaired one of the concorso committees whose activities are being challenged, and has already been denounced by two members of his committee.

All recommendations of concorsi com-

\section{El Niño centre is forecasting 'first'}

Washington. Scientists and government officials from 40 countries last week endorsed plans for an international research centre to forecast the impact of the El Niño effect on global climate. Supporters of such a centre say that it could eventually generate regular, reliable global forecasts of short-term climate change.

The proposed international research institute will be funded initially by the United States, and located at one of eight competing US universities. It will refine existing models of El Niño and issue global forecasts of its likely impact. Such forecasts will enable farmers to select crops for planting in advance of EI Niño's impact possibly averting huge crop losses in areas where rainfall is influenced by $\mathrm{El}$ Niño.

The El Niño-Southern Oscillation, an interaction between the Pacific Ocean and the air above it, is a central factor in short-term climate variation around the world, particularly in the tropics. The warm and cold El Niño cycle has a particularly strong impact on rainfall, and therefore agriculture, in large areas of South America and south and South-East Asia.

The planned centre is seen as an important precedent by climatologists, as it would make available for the first time a full forecasting service based on global climate models. "This is the first step towards longterm climate forecasts," says James Baker, administrator of the US National Oceanic and Atmospheric Administration (NOAA), and co-host of the intergovernmental meeting in Washington last week.
Jack Gibbons, President Bill Clinton's science adviser and the other co-host, told the meeting that early predictions of a drought associated with El Niño in 1992 had enabled farmers in Brazil to maintain production "at near-normal levels", in contrast to a previous, similar pattern in 1987, when production had fallen by 85 per cent.

"The economic benefits of being able to avert crop failures could be worth billions of dollars to us, collectively, every year," said Gibbons. "By working together to improve understanding of the EI Niño phenomenon and to produce and disseminate climate forecasts, we can use that knowledge for the betterment of the human condition."

According to NOAA officials, the site of the new international institute will be selected within a few weeks. The agency has budgeted $\$ 4$ million in the first year to set up the centre, which could be fully operational within 12 to 18 months.

As well as issuing forecasts and working systematically to refine their accuracy, the institute will seek to speed up the application of climate science to social needs and help poorer countries to make good use of the forecasts.

Last month, the US weather service issued its own forecast that, with sea surface temperatures in the Pacific at or just below normal, the global climate this winter would not be strongly influenced by El Niño conditions. The full forecast is available on the World Wide Web at http://nic.fb4.noaa.gov. Colin Macilwain mittees must be approved by the National University Council (CUN), a body that advises the minister of universities and research on university issues, as well as by the minister himself. But both are now attempting to disclaim responsibility.

In an article in the daily Corriere della Sera, Luigi Frati, dean of the faculty of medicine in Rome's La Sapienza university, argues that the CUN lacks the power to do much more than check that the formal administrative procedures of concorsi are carried out. He points out that Salvini had promised a reform of the whole system of academic appointments, but this has not yet happened.

Last week, D'Ippolito called in several high-level 'expert witnesses' to help him to assess the cases now before the courts. These witnesses included Salvini and his predecessor Stefano Podestá.

Asked to explain why he had approved six contested concorsi decisions, mostly relating to medical sciences, that were not approved by Podestá, Salvini argued that his duty, like that of the CUN, is limited to approving the way in which the formal procedures of the concorsi are carried out, rather than examining individual recommendations for promotion.

By contrast, Podestá told D'Ippolito that he had not signed the six concorsi in question because he felt that personal interests might have been operating within the committees. "I believe a minister should not be a paper-pusher," he said.

Earlier this year, Salvini proposed legislation to change the rules of the concorsi, allowing more candidates to be selected than the number of positions available (see Nature 374, 756; 1995). This would permit individual universities to make their own appointments from a short-list, instead of being assigned a new staff member by a national committee.

Yet despite assurances that the bill would be given priority in parliament, it quickly became mired in committees by discussions and counter-proposals, and is now unlikely to be approved in the near future. As a result, Salvini has decided not to wait for a change in the rules before setting up the next round of concorsi, keen to alleviate the block that has built up in the lower ranks of academia appointments.

Even if the bill were to be approved, many believe that it would not go far enough. Fernando Auiti, for example, a professor of immunology at La Sapienza who was also called in as a witness by D'Ippolito, is one of many who argue that objective criteria, such as publication citation rates, should be obligatory within the concorso process. "This is normal practice in the world of international science," he points out. 